\title{
PENGARUH RELAKSASI OTOT PROGRESIF TERHADAP TINGKAT STRESS PADA MAHASISWA S1 SEMESTER AKHIR FAKULTAS EKONOMI JURUSAN MANAGEMENT KEUANGAN UNIVERSITAS PAMULANG
}

\author{
*Rita Dwi Pratiwi, **Sri Haryanto \\ Program Studi S1 Keperawatan, STIKes Widya Dharma Husada Tangerang \\ Jalan Pajajaran No1, Pamulang Tangerang Selatan Banten \\ ritadwipratiwi@wdh.ac.id
}

\begin{abstract}
Abstrak
Menurut American Psychological Association, 2013 Stress diartikan sebagai tekanan, ketegangan atau gangguan yang tidak menyenangkan yang berasal dari luar diri seseorang. Mahasiswa yang menghadapi skripsi biasanya ada hambatan seperti memikirkan proses pencarian data, kejenuhan. Dan kesulitan membagi waktu antara mengerjakan skripsi dengan aktifitas lainnya sehingga skripsi membuat seseorang stress. Penanganan stress dapat dilakukan pada mahasiswa tingkat akhir adalah salah satunya cara terapi non farmokologi yaitu dengan latihan relaksasi otot progresif. Tujuan umum penelitian ini adalah untuk mengetahui pengaruh teknik relaksasi otot progresif terhadap tingkat stress pada mahasiswa S1 semester akhir fakultas ekonomi jurusan management keuangan Universitas Pamulang. Penelitian ini menggunakan metode eksperimen dengan Pra eksperimen One-Group Pretest-Posttest design. Teknik pengambilan sampel pada penelitian ini adalah non probability sampling dengan metode purposive sampling dengan sampel berjumlah 127 responden. Berdasarkan uji Wilcoxon. Didapatkan hasil tingkat stress mahasiswa sebelum diberikan teknik relaksasi otot progresif berada pada kategori stress ringan $(48,8 \%)$ dan stress berat $(48,8 \%)$, Setelah diberikan ROP hampir seluruh adanya penurunan tingkat stress berada pada kategori ringan (95,3\%). Dari uji statistik didapatkan hasil pengaruh terapi relaksasi otot progresif terhadap tingkat stres mahasiswa dengan p-value 0,000 Maka disimpulkan ada pengaruh antara relaksasi otot progesif terhadap tingkat stress mahasiswa S1 semester akhir fakultas ekonomi jurusan management keuangan Universitas Pamulang. Disarankan untuk mahasiswa solusi yang dapat membantu mahasiswa mengurangi tingkat stress, disarankan bagi intansi pendidikan dapat menjadi salah satu sumber pustaka dan informasi baru untuk menambah wawasan bagi mahasiswa maupun dosen terutama dalam penanganan management stress.
\end{abstract}

Kata kunci : Stress mahasiswa, Relaksasi otot progresif

\begin{abstract}
According to the American Psychological Association, 2013 stress defined as pressure, tension or unpleasant disorder that come from outside individual. Students writing a mini thesis usually face obstacles such as thinking of data collecting, boredom and time management between writing mini thesis and other activities so that mini thesis makes them stress. Stress handling can be done on the last semester students, one of them is non-Pharmacological therapy by doing progressive muscle relaxation. The general aim of this research is to find out the influence of progressive muscle relaxation technique with to the stress level on the last semester students of faculty economics, finance management department, Pamulang University. This research used experiment method with Pre-experiment One-Group Pretest-Posttest design. Sampling technique in this research was non-probability sampling with purposive sampling method with the number of samples as many as 127 respondents. Based on Wilcoxon test, it was found that the stress level of students prior to be given progressive muscle relaxation were on the light stress category $(48,8 \%)$ and hard stress $(48,8 \%)$. After being given ROP, almost students were on the light stress category (95,3\%). Of statistical test, it was obtained the result of effect of progressive muscle relaxation to the stress level on the students with p value 0,000. It was concluded that the effect of the progressive muscle relaxation to the last semester students of finance management department of faculty of economics, Pamulang university. It is suggested that students do progressive muscle relaxation to reduce stress level. It is also suggested to the educational education that it become the source of references and new information in order to upgrade their knowledge for both students and lecturers to practice stress management.
\end{abstract}

Keywords $\quad$ : Students Stress, Progressive Muscle Relaxation 


\section{PENDAHULUAN}

Skripsi merupakan karya tulis ilmiah dari hasil penelitian atau percobaan yang disusun oleh mahasiswa dibawah bimbingan dosen pembimbing skripsi oleh karena itu skripsi dipertanggung jawabkan dalam suatu sidang ujian akhir program atau sidang skripsi, mahasiswa yang menghadapi skripsi biasanya ada berbagai hambatan seperti memikirkan proses pencarian data dan mengumpulkan data, kejenuhan, dan kesulitan membagi waktu antara mengerjakan skripsi dengan aktifitas lainnya.

Hal-hal tersebut akan mengakibatkan stress, tidak percaya diri, emosional, kehilangan motivasi sehingga penyusunan skripsi bisa menunda dan tidak menyelesaikan sehingga skripsi menjadi hambatan yang tidak segera di tanggani.

Menurut (American Psychological Association, 2013) Stres juga bisa diartikan sebagai tekanan, ketegangan atau gangguan yang tidak menyenangkan yang berasal dari luar diri seseorang. Menurut (Klinic Community Health Centre, 2010) Bahwa penyebab stress dapat dipicu karena lingkungan, stressor lingkungan, fisiologis, pikiran, maupun proses pembelajaran (Jihan Nisa Afdila, 2016).

Penanganan stress bisa dari farmakologi dan non farmakologi, Salah satu penurunan tingkat stress non farmakologi yaitu relaksasi otot, relaksasi otot progresif yang merupakan salah satu jenis terapi relaksasi dengan cara menegangkan otot tertentu kemudian melepaskan ketegangan itu, relaksasi otot progresif juga mengunankan metode yang terdiri dan peregangan dan relaksasi sekelompok otot dan mengurangi ketegangan otot pada perasaan rileks (Muliyana, 2015).

Penelitian yang pernah dilakukan di Universitas Islam Negeri Sunan Ampel menyatakan bahwa tingkat stres mahasiswa yang mengerjakan skripsi yaitu 30,76\% stres tinggi dan 69,23\% stres sedang. Menurut (Gita Augesti Dkk, 2015). Di Malaysia prevalensi stres mahasiswa fakultas kedokteran adalah 41,9\%. 4 Penelitian serupa juga pernah dilakukan pada salah satu universitas di Indonesia. Hasil penelitian tersebut didapatkan gambaran tingkat stres pada mahasiswa kedokteran sebesar 71\%.5 Secara keseluruhan, prevalensi stres pada mahasiswa fakultas kedokteran 
masih cukup tinggi, yaitu berkisar 30$70 \%$.

Berdasarkan uraian di atas peneliti tertarik membahas tentang "Pengaruh Relaksasi Otot Progresif Terhadap Tingkat Stress Mahasiswa S1 Semester Akhir Fakultas Ekonomi Jurusan Management Universitas Pamulang”.

\section{METODE}

\section{Desain Penelitian}

Penelitian ini menggunakan metode penelitian eksperimen dengan desain penelitian ini adalah Pre-Experimental One-Group Pretest-Posttest design

\section{Lokasi dan Waktu Penelitian}

Lokasi penelitian di Fakultas Ekonomi jurusan Management Keuangan Universitas Pamulang pada bulan Mei Juni 2018

\section{Populasi}

Populasi dalam penelitian ini adalah seluruh mahasiswa S1 semester akhir fakultas ekonomi jurusan management keuangan Universitas Pamulang yang berjumlah 199 orang, pada studi pendahuluan ada 10 orang maka populasi yang didapatkan yaitu 189 orang

\section{Sampel}

Sampel dalam penelitian ini adalah berjumlah 127 responden mahasiswa semester akhir Fakultas Ekonomi jurusan Management keuangan Universitas Pamulang

Tehnik pengambilan sampel pada penelitian ini adalah menggunakan tehnik nonprobability sampling dengan metode purposive sampling.

\section{Analisis Data}

Analisis univariate dalam penelitian ini terdiri dari karakteristik responden (jenis kelamin, umur, status tinggal, aktifitas selain kuliah dua variabel yaitu relaksasi otot progresif sebagai variabel independent dan tingkat stress sebagai variabel dependent.

Analisis bivariate dalam penelitian ini untuk mengetahui pengaruh relaksasi otot progresif terhadap tingkat stress pada kelompok intervensi Mahasiswa S1 semester akhir jurusan management keuangan di Universitas Pamulang. 


\section{HASIL PENELITIAN}

\section{ANALISIS UNIVARIAT}

Tabel $5.1 \quad$ Distibusi $\quad$ Frekuensi Karakteristik Responden Menurut Jenis Kelamin Di Fakultas Ekonomi Jurusan Management Keuangan Universitas Pamulang.

\begin{tabular}{lcc}
\hline Jenis kelamin & Frekuensi & Presentase(\%) \\
\hline Laki-laki & 26 & 20,5 \\
Perempuan & 101 & 79,5 \\
\hline \hline Total & 127 & 100 \\
\hline
\end{tabular}

Dari Tabel 5.1. diatas diketahui bahwa hampir seluruhnya responden yang berjenis kelamin perempuan yaitu sebanyak 101 responden $(79,5 \%)$, dan untuk laki-laki sebanyak 26 responden $(20,5 \%)$.

Tabel 5.2 Distibusi $\quad$ Frekuensi Karakteristik Responden Menurut Umur Di Fakultas Ekonomi Jurusan Management Keuangan Universitas Pamulang.

\begin{tabular}{ccc}
\hline Umur Responden Frekuensi & Persentase $(\%)$ \\
\hline 21 Tahun & 49 & 38,6 \\
22 Tahun & 60 & 47,2 \\
23 Tahun & 11 & 8,7 \\
24 Tahun & 6 & 4,7 \\
25 Tahun & 1 & 0,8 \\
\hline \hline
\end{tabular}

\begin{tabular}{ccc}
\hline \hline Total & 127 & 100 \\
\hline
\end{tabular}

Dari Tabel 5.2. diatas diketahui bahwa hampir dari setengahnya responden berada pada kelompok umur 22 tahun sebanyak $60(47,2 \%)$, umur 21 tahun sebanyak $49(38,6 \%)$, umur 23 tahun sebanyak $11(8,7 \%)$, umur 24 tahun sebanyak $6(4,7 \%)$ dan umur 25 tahun sebanyak $1(0,8 \%)$.

\section{Tabel 5.3 Distibusi Frekuensi} Karakteristik Responden Menurut Status Tempat Tinggal Di Fakultas Ekonomi Jurusan Management Keuangan Universitas Pamulang.

\begin{tabular}{lcl}
\hline Status Tinggal & Frekuensi & Persentase(\%) \\
\hline Bersama Orang Tua & 104 & 81,9 \\
Kost & 20 & 15,7 \\
Lain-lain & 3 & 2,4 \\
\hline \hline Total & 127 & 100 \\
\hline
\end{tabular}

Dari Tabel 5.3. diatas diketahui bahwa hampir seluruh responden yang tinggal bersama orang tua sebanyak 104 responden $(81,9 \%)$, responden yang kost sebanyak 20 responden $(15,7 \%)$ dan lain-lain sebanyak 3 responden $(2,4 \%)$.

\section{Tabel 5.4 Distibusi Frekuensi}

Karakteristik Responden Aktivitas Selain Kuliah Di Fakultas Ekonomi Jurusan Management Keuangan Universitas Pamulang.

Aktivitas Selain Kuliah Frekuensi (\%) 


\begin{tabular}{llc}
\hline Kerja Freelance/fulltime & 41 & 32,3 \\
Olahraga & 28 & 22,0 \\
Organisasi & 22 & 17,3 \\
Lain-Lain & 36 & 28,3 \\
\hline \hline Total & 127 & 100 \\
\hline
\end{tabular}

Dari Tabel 5.4. diatas diketahui bahwa hampir dari setengah responden yang aktivitas selain kuliah yaitu bekerja sebanyak 41 responden $(32,3 \%)$, LainLain sebanyak 36 responden (28.3\%), Olahraga sebanyak 28 responden $(22,0 \%)$, dan organisasi sebanyak 22 responden $(17,3 \%)$.

Tabel 5.5 Distibusi Frekuensi Karakteristik Responden Berdasarkan Tingkat Stress Sebelum Dilakukan Intervensi Di Fakultas Ekonomi Jurusan Management Keuangan Universitas Pamulang.

\begin{tabular}{lcc}
\hline Pretest & Frekuensi & Persentase (\%) \\
\hline Stress Ringan & 62 & 48,8 \\
Stress Sedang & 62 & 48,8 \\
Stress Berat & 3 & 2,4 \\
\hline Total & 127 & 100 \\
\hline
\end{tabular}

Dari Tabel 5.5 diatas diketahui bahwa berdasarkan tingkat stress sebelum intervensi hampir dari setengah responden mengalami stress ringan sebanyak 62 responden $(48,8 \%)$, stress sedang sebanyak 62 responden $(48.8 \%)$ dan Stress berat sebanyak 3 responden $(2,4 \%)$.

Tabel 5.6 Distibusi Frekuensi Karakteristik Responden Berdasarkan Tingkat Stress Sesudah Dilakukan Intervensi Di Fakultas Ekonomi Jurusan Management Keuangan Universitas Pamulang.

\begin{tabular}{lrc}
\hline Posttest & Frekuensi & Persentasi (\%) \\
\hline Stress Ringan & 121 & 95,3 \\
Stress Sedang & 6 & 4,7 \\
\hline Total & 127 & 100 \\
\hline
\end{tabular}

Dari Tabel 5.6 diatas diketahui bahwa hampir seluruh responden mengalami tingkat stress sesudah intervensi yaitu stress ringan sebanyak 121 responden $(95,3 \%)$, stress sedang sebanyak 6 responden $(4,7 \%)$.

Tabel 5.7 Analisis Pengaruh relaksasi Relaksasi Otot Progresif Terhadap Tingkat Stress Pada Mahasiswa S1 Semester Akhir Fakultas Ekonomi Jurusan Management Keuangan Universitas Pamulang. 


\begin{tabular}{llrrr}
\hline Posttest - Pretest Negative Ranks & $61^{\mathrm{a}}$ & 31.00 & 1891.00 \\
Positive Ranks & $0^{\mathrm{b}}$ & .00 & .00 \\
Ties & $66^{\mathrm{c}}$ & & \\
\hline Total & 127 & & \\
\hline
\end{tabular}

Tabel 5.8 Hasil Analisa Uji Wilcoxon Relaksasi Otot Progresif Sebelum (Pre) dan Sesudah $($ Post $)(\mathbf{N}=127)$

\begin{tabular}{lccc}
\hline \multicolumn{1}{c}{ Relaksasi Otot Progresif } & Mean Rank & Sum Of Rank & P value \\
\hline $\begin{array}{l}\text { Relaksasi Otot Progresif sebelum } \\
\text { Perlakuan }\end{array}$ & 0,00 & 0,00 & \\
\hline $\begin{array}{l}\text { Relaksasi Otot Progresif sesudah } \\
\text { Perlakuan }\end{array}$ & 31,00 & 1891.00 & 0,000 \\
\hline
\end{tabular}

Diketahui dari hasil uji statistik intervensi relaksasi otot progresif tingkat menunjukkan bahwa adanya pengaruh relaksasi otot progresif terhadap penurunan tingkat stress mahasiswa fakultas ekonomi jurusan management stress tidak mengalami perbedaan.

\section{PEMBAHASAN}

Dari tabel 5.1 diatas dalam penelitian ini jumlah mahasiswa yang

keuangan Universitas Pamulang dengan hasil $p$ value $=0,000<$ nilai $\alpha=0,05$ dan terdapat penurunan tingkat stress setelah diberikan relaksasi otot progresif dengan frekuensi sebanyak 61 responden mengalami penurunan sesudah dilakukan relaksasi otot progresif, tidak ada responden (0 responden) responden yang mengalami peningkatan tingkat stress sesudah dilakukan intervensi relaksasi otot progresif dan 66 responden sebelum dan sesudah dilakukan didapatkan menjadi 2 kelompok yaitu, perempuan $79,5 \%$ dan laki-laki $20,5 \%$. Sebagian besar pada jurusan management keuangan Universitas Pamulang pada semester akhir berdominan berjenis kelamin perempuan.

Menurut (Muhammad Nawir, 2015) Perbedaan yang ada antara wanita dengan pria seharusnya tidak menjadi sebuah masalah yang dapat 
menyebabkan kesenjangan diantara keduanya. Banyak pandangan yang seakan-akan menilai bahwa posisi wanita selalu lebih rendah dibandingkan dengan pria. Pria memiliki wewenang yang lebih banyak daripada wanita dalam segala hal, termasuk di dalam sebuah keluarga. Ada beberapa faktor yang menyebabkan perbedaan itu terjadi. Faktor biologis atau genetis merupakan suatu hal yang mutlak dan tidak dapat dirubah karena sudah berasal dari lahir. Sedangkan faktor lingkungan berhubungan dengan adanya perbedaan peranan antara wanita dan pria. Wanita hanya dibatasi oleh peranan internal dimana hanya mengurusi persoalan yang ada di dalam rumah tangga saja.

Berdasarkan teori Kaplan dan Sadock cit Indah Puspasari Kiay Demak, 2016 menyatakan bahwa stress terjadi lebih banyak pada wanita. Perempuan memilki tingkat stress yang tinggi karena akibat dari reaksi saraf otonom yang berlebihan dengan naiknya sistem simpatis, naiknya norepineprin, terjadi peningkatan pelepasan kotekalamin, dan adanya gangguan regulasi serotonergik yang abnormal.

Berarti dalam hal ini perbedaan jenis kelamin tidak menjadi sebuah masalah antara laki-laki dan perempuan, sehingga derajat keduanya tidak adanya perbedaan peranan antara laki-laki dan perempuan.

Dari tabel 5.2 diatas karakteristik mahasiswa berdasarkan umur dikelompokan menjadi 5 yaitu mahasiswa umur 21 sebanyak 38,6\%, mahasiswa umur 22 sebanyak 47,2\%, umur 23 sebanyak 8,7\%, umur 24 sebanyak 4,7\%, umur 25 sebanyak 0,8\%. Menurut (Handini Agusdwitanti, 2015) setiap manusia dalam kehidupannya pasti menjalani tahapan perkembangan salah satunya tahap perkembangan tersebut adalah masa dewasa awal, masa dewasa awal (young adulthood) berkisar antara usia 20 - 40 tahun.

Berdasarkan teori (Santrock, 2003 dalam Noviani Endah Budi Astuti) Masa dewasa awal (early adulthood) merupakan masa untuk membentuk kemandirian pribadi dan ekonomi. Tanda dimulainya masa dewasa ditentukan oleh standar budaya dan pengalaman. Bagi kebanyakan individu yang berada pada masa dewasa awal, memilih pasangan, belajar hidup dengan seseorang secara intim dan memulai keluarga merupakan kegiatan yang banyak menyita waktu. Individu dikatakan menjadi dewasa apabila berani 
menerima tanggung jawab atau akibat dari tindakan sendiri, dan menentukan nilai dan keyakinan sendiri. Berdasarkan teori (Manuaba dalam Indah Puspasari Kiay Demak, 2016) menyatakan bahwa usia muda lebih mudah terkena tekanan (stres) psikologis dan cemas, karena kesiapan mental dan jiwa yang belum matang serta kurangnya pengalaman.

Berdasarkan teori Aris Kurniawan (2016) Mahasiswa adalah setiap orang yang secara terdaftar untuk mengikuti pelajaran disebuah perguruan tinggi dengan batasan umur sekitar $18-30$ tahun. Mahasiswa merupakan suatu kelompok dalam masyarakat yang memperoleh statusnya, karena adanya ikatan dengan suatu perguruan tinggi.

Berarti dalam hal ini yang dikatakan dewasa awal berumur antara 18-30 tahun, sudah berani menerima dan memiliki tanggung jawab terhadap setiap masalah individual. Dewasa awal atau usia muda lebih mudah terkena stress atau emosional yang tidak bisa dikendalian karena masih kurangnya pengalaman oleh karena itu dewasa awal harus memikirkan hal-hal yang positif untuk mengendalikan emosionalnya.

Dari tabel 5.3 diatas dalam penelitian ini karakteristik status tinggal memiliki 3 kategori yaitu tinggal bersama orang tuanya sebanyak $81,9 \%$, ngekost $15,7 \%$, dan lain-lain sebanyak 2,4\%. Mayoritas dalam penelitian ini mahasiswa tinggal bersama orang tuanya.

Menurut (Margareth Sutjiato, 2015) Stress sendiri bisa berasal dari individu, lingkungan keluarga, lingkungan tempat tinggal dan dapat pula berasal dari tempat dimana individu banyak menghabiskan waktunya seperti kantor dan tempat pendidikan. Faktor-faktor yang dapat menyebabkan stress dapat dibagi atas faktor internal dan faktor eksternal. Faktor internal yang berasal dari dalam diri individu mahasiswa sendiri misalnya kondisi fisik, motivasi, dan tipe kepribadian dari mahasiswa itu sendiri. Faktor eksternal biasanya berasal dari luar individu seperti keluarga, pekerjaan, fasilitas, lingkungan, dosen dan lain-lain.

Berdasarkan teori (Margareth Sutjiato, 2015) bahwa responden yang kost belum tentu lebih mudah mengalami stress dibandingkan yang tinggal dengan keluarga. Hal ini dikarenakan di tempat kost banyak teman-teman sebaya yang bisa menolong atau memberikan masukkan saat ada masalah di kampus. Begitupun 
dengan responden yang tinggal dengan keluarga belum tentu mereka tidak akan mengalami stress. Bisa jadi justru dirumah, mereka mengalami banyak tekanan yang mungkin di dapat dari orang tua yang terlalu memberikan banyak tekanan. Belum juga lingkungan sekitar rumah yang tidak mendukung selama masa perkuliahan.

Berarti dalam hal ini tempat tinggal bisa memicu terjadinya stress bahwasannya setiap individual harus mempunyai tuntutan jenjang pendidikan yang harus ditempuh oleh setiap individual.

Dari tabel 5.4 diatas dalam penelitian ini mahasiswa yang memiliki aktivitas selain kuliah ada 4 kategori yaitu kerja freelance/full time sebanyak 32,3\%, berolahraga sebanyak $22 \%$, mengikuti organisasi sebanyak 17,3\%, dan lain-lain sebanyak 28,3. Mayoritas mahasiswa memiliki aktivitas selain kuliah yaitu kerja.

Menurut (Margareth Sutjiato, 2015) Stress sendiri bisa berasal dari individu, lingkungan keluarga, lingkungan tempat tinggal dan dapat pula berasal dari tempat dimana individu banyak menghabiskan waktunya seperti kantor dan tempat pendidikan. Tuntutan eksternal dapat bersumber dari tugastugas kuliah, beban pelajaran, tuntutan orang tua untuk berhasil di kuliahnya, dan penyesuaian sosial di lingkungan kampusnya. Tuntutan ini juga termasuk kompetensi perkuliahan dan meningkatnya kompleksitas materi perkuliahan yang semakin lama semakin sulit. Tuntutan dari harapan mahasiswa dapat bersumber dari kemampuan mahasiswa dalam mengikuti pelajaran.

Berarti dalam hal ini bahwa seseorang yang kuliah sambil bekerja harus bisa membagi waktu antara tuntutan eksternal maupun internal.

Berdasarkan tabel 5.8 menunjukkan bahwa relaksasi otot progresif sebelum dan sesudah perlakuan didapatkan ratarata (mean rank) sebelum dan sesudah relaksasi otot progresif didaptakan ratarata (mean rank) sbelum relaksasi otot progresif adalah 0,00 (sum of rank = 0,0 ), dan rata-rata (mean rank) sesudah relaksasi otot progresif adalah 31,00 (sum of rank $=1891.00)$, Nilai $P$ value $=$ 0,000 pada crombach alpha $<0,05$ maka ada perbedaan relaksasi otot progresif sesudah dah sebelum perlakuan.

Penelitian ini didukung oleh teori Setyoadi dan Kushariyadi (2013) Yang bahwa terapi relaksasi otot progresif 
dapat digunakan bagi responden yang mengalami gangguan tingkat stress, insomnia, kecemasan, dan depresi. Relaksasi otot progresif ini bertujuan untuk menurunkan ketegangan otot, mengurangi kecemasan, nyeri leher dan punggung, mengurangi aktivitas frekuensi jantung dan meningkatkan rasa kebugaran, konsentrasi. Serta memperbaiki kemampuan untuk mengatasi stress, kelelahan, spasme otot dan membangun emosi positif dari emosi negatif.

Penelitian ini sejalan dengan penelitian Zulfiana Prasetya, 2016 dalam penelitiannya bahwa Jenis penelitian yang digunakan adalah Pra eksperimen yang termasuk ke dalam pretest and postest one group design. Analisa data statistik yang digunakan adalah Paired $t$ test. Pengumpulan data yang dilakukan pada saat sebelum dan sesudah latihan relaksasi otot progresif. Berdasarkan uji statistik di dapatkan $P$ value $=0,000$, yang berarti terdapat perbedaan bermakna sebelum dan sesudah terapi relaksasi otot progresif. Terapi relaksasi otot progresif adalah salah satu intervensi yang dapat digunakan untuk menurunkan tingkat insomnia pada lansia dan merupakan salah satu teknik untuk mengurangi ketegangan otot dengan proses yang simple dan sistematis dalam menegangkan sekelompok otot kemudian merilekskannya kembali yang dimulai dari otot wajah dan berakhir pada otot kaki.

Penelitian terkait lainnya dilakukan oleh (Irma, 2015) Dalam penelitian ini bahwasannya hasil analisis data penelitian menggunakan uji beda Wilcoxon Signed Ranks test pada sebelum dan sesudah terapi relaksasi otot progresif. Diperoleh hasil $\mathrm{Z}=$ 2.201dengan nilai signifikansi $\mathrm{p}=0.014$ $(\mathrm{p}<0.05)$ (Level of significance for onetailed). Maka dapat disimpulkan bahwa ada perbedaan yang signifikan pada stres kerja pada perawat setelah diberikan terapi relaksasi otot progresif. Berdasarkan hasil analisis kuantitatif yang telah dipaparkan maka dapat disimpulkan bahwa hipotesis penelitian ini diterima, yaitu terapi relaksasi otot progresif dapat menurunkan stres kerja pada perawat panti wredha Elim.

Berarti dalam hal ini relaksasi otot progresif bisa mengendalikan tingkat stress mahasiswa dan bisa jadi pengetahuan untuk individual yang stress. Sehingga salah satu non 
farmakologi untuk menurunkan tingkat stress yaitu dengan cara merileksan otototot dan merileksan fikiran.

\section{KESIMPULAN DAN SARAN}

\section{Kesimpulan}

Berdasarkan hasil penelitian yang telah dilakukan maka dapat diambil kesimpulan sebagai berikut :

1. Berdasarkan karakteristik responden

a. Gambaran karakteristik responden dengan jumlah 127 mahasiswa berdasarkan jenis kelamin, didapatkan hasil responden yang berjenis kelamin hampir seluruhnya sebanyak 101 responden (79,5\%) dan Laki-laki sebanyak 26 responden $(20,5 \%)$.

b. Gambaran karakteristik responden dengan jumlah 127 mahasiswa berdasarkan umur didapatkan hasil hampir setengah dari responden yang berumur 22 tahun sebanyak 60 responden (47,2\%), umur 21 tahun sebanyak 49 responden $(38,6 \%)$, umur 23 tahun sebanyak 11 responden $(8,7 \%)$, umur 24 tahun sebanyak 6 responden $(4,7 \%)$, umur 25 tahun sebanyak 1 responden $(0,8 \%)$.

c. Gambaran karakteristik responden dengan jumlah 127 mahasiswa berdasarkan tempat tinggal. Yang tinggal bersama orang tua hampir seluruhnya sebanyak 104 responden (81,9\%), yang kost sebanyak 20 responden $(15,7 \%)$, dan lain-lain sebanyak 3 responden $(2,4 \%)$.

d. Gambaran karakteristik responden dengan jumlah 127 mahasiswa berdasarkan aktivitas selain kuliah hampir setengah responden sebanyak 41 responden (32,3\%), Lain-lain sebanyak 36 responden (28,3\%), olahraga sebanyak 28 responden (22\%), dan organisasi sebanyak 22 responden $(17,3 \%)$.

e. Gambaran karakteristik responden dengan jumlah 127 mahasiswa berdasarkan tingkat stress mahasiswa sebelum intervensi adalah hampir seluruh mahasiswa yang mengalami stress ringan sebanyak 62 responden (48,8\%), stress sedang sebanyak 62 responden $(48,8 \%)$ dan mahasiswa yang mengalami 
stress berat sebanyak 3 responden $(2,4 \%)$.

f. Gambaran karakteristik responden dengan jumlah 127 mahasiswa berdasarkan hasil, tingkat stress mahasiswa sesudah intervensi mengalami hampir semua penurunan relaksasi otot progresif dengan tingkat stress ringan sebanyak 121 responden $(95,3 \%)$.

g. Diketahui dari hasil uji statistik menunjukkan bahwa adanya pengaruh relaksasi otot progresif terhadap penurunan tingkat stress mahasiswa fakultas ekonomi jurusan management keuangan Universitas Pamulang dengan hasil $p$ value $=0,000<$ nilai $\alpha=$ 0,05 dan terdapat penurunan tingkat stress setelah diberikan relaksasi otot progresif dengan frekuensi sebanyak 61 responden mengalami penurunan sesudah dilakukan relaksasi otot progresif, tidak ada responden $(0$ responden) responden yang mengalami peningkatan tingkat stress sesudah dilakukan intervensi relaksasi otot progresif dan 66 responden sebelum dan sesudah dilakukan intervensi relaksasi otot progresif tingkat stress tidak mengalami perbedaan.

\section{Saran}

1. Bagi Mahasiswa

Hasil penelitian ini diharapkan dapat menjadi sumber informasi dan solusi yang dapat membantu mahasiswa dapat mengurangi tingkat stress ketika menghadapi skripsi dengan penggunaan metode relaksasi otot progresif yang dapat dilakukan dimana saja dan kapan saja. Sehingga dengan mudah mengontrol stressor yang menyebabkan tingkat stress bagi mahasiswa.

2. Bagi Instansi Pendidikan

Hasil penelitian ini diharapkan dapat menjadi salah satu sumber pustaka dan informasi baru untuk menambah wawasan bagi mahasiswa maupun dosen dalam proses perkuliahan terutama dalam penanganan management tingkat stress

3. Bagi Peneliti Selanjutnya

Bagi peneliti selanjutnya disarankan untuk meneliti lebih lanjut tentang penanganan atau management stress pada mahasiswa tingkat akhir dalam 
menghadapi skripsi baik itu menggunakan variabel-variabel yang terkait dengan tingkat stress.

\section{DAFTAR PUSTAKA}

A, Lukluk Zuyina. Bandiyah, Siti. 2011. Psikologi kesehatan. Yogyakarta. Nuha Medika

Afdila, Jihan Nisa. (2016). Pengaruh Terapi Guided Imagery Terhadap Tingkat Stres Pada Mahasiswa Tingkat Akhir Dalam Menyelesaikan Skripsi. Diakses pada tanggal 1 April 2018

Alimul, Aziz H. (2011). Metode Penelitian Keperawatan Dan Teknik Analisis Data. Jakarta: Salemba Medika.

American Psychological Association. (2013). Stress in America: missing the health care connection (Online Journal).

Augesti, Gita Dkk. (2015). Differences In Stress Level Between First Year And Last Year Medical Students In Medical Faculty of Lampung Universitas.

Budi Astuti, Noviani Endah. (2015). Penyesuaian Diri Wanita Dewasa Awal Ditinjau Dari Kematangan Emosi. Fakultas Psikologi Universitas Semarang.

Cahyo Broto, Henricus Dimas Frandi. (2016). Stress Pada Mahasiswa Penulis Skripsi (Studi Kasus Pada Salah Satu Mahasiswa Program Studi Bimbingan Dan Konseling
Universitas Sanata Dharma). Diakses pada tanggal 1 April 2018.

Christyanti, Dika Dkk. (2010). Hubungan Antara Penyesuaian Diri Terhadap Tuntutan Akademik Dengan Kecenderungan Stress Pada Mahasiswa Fakultas Kedokteran Universitas Hang Tuah Surabaya. Diakses pada tanggal 12 April 2018.

Dahlan, M Sopiyudin. (2014). Statistik Untuk Kedokteran Dan Kesehatan Edisi 6. Jakarta, Salemba Medika.

Hawari, Dadang. (2016). Management Stress Cemas Dan Depresi. Jakarta : Badan Penerbit FKUI Jurnal Equilibrium

Kiay Demak, Indah Puspasari. (2016). Hubungan Umur, Jenis Kelamin Mahasiswa Dan Pendapatan Orang Tua Dengan Tingkat Kecemasan Pada Mahasiswa Pendidikan Sarjana Program Studi Pendidikan Dokter Fkik Universitas Tadulako. Medika Tadulako.

Klinic Community Health Center. (2010). Stress And Stress Management.

Kristianti, Erna. (2016). Hubungan Stress Kerja Dengan Kinerja Perawat Dalam Pendokumentasian Asuhan Keperawatan Di Ruang Perawatan Khusus RSUD $d r$. Soediran Mangun Sumarso Wonogiri. Diakses pada tanggal 12 April 2018.

Li, Yunping Dkk. (2015). Progressive Muscle Relaxation Improves Anxiety And Depression Of 
Pulmonary Arterial Hypertension Patients. Hindawi Publishing Corporation.

Mubarak, Wahid Iqbal Dkk. (2015). Buku Ajar Ilmu Keperawatan Dasar Buku I. Jakarta: Salemba Medika

Muliyana. (2015). Pengaruh terapi relaksasi otot progresif terhadap perubahan tingkat insomnia pada lansia di RT 04 RW o4 kelurahan Tanjung duren Jakarta Barat. Universitas Esa Unggul

Murti, Tri. (2012). Perbedaan Tekanan Darah Pada Pasien Hipertensi Esensial Sebelum Dan Sesudah Pemberian Relaksasi Otot Progresif Di RSUD Tugurejo Semarang. UNIMUS Semarang.

Mustikawati, Irma Finurina. (2015). Efek Terapi Relaksasi Otot Progresif Dalam Menurunkan Tingkat Stres Kerja Pada Perawat Panti Wredha Elim Di Semarang. Diakses pada tanggal 10 April 2018.

Nawir, Muhammad Dkk. (2015). Subordinasi Anak Perempuan Dalam Keluarga.

Notoatmodjo, Soekidjo. (2012). Metodologi Penelitian. Jakarta: Rineka Cipta.

Prasetya, Zulfiana. (2016). Pengaruh Terapi Relaksasi Otot Progressif Terhadap Perubahan Tingkat Insomnia Pada Lansia. Universitas Islam Negeri Alauddin Makassar.

Priyoto. (2014). Konsep Manajemen Stress. Yogyakarta. Nuha Medika.
Puspitha, Farras Cahya. (2017). Hubungan Stress Terhadap Motivasi Belajar Mahasiswa Tingkat Pertama Fakultas Kedokteran Universitas Lampung. Diakses 9 April 2018.

Rahma, Alia Dkk. (2015). Hubungan tingkat stres menghadapi tugas akhir skripsi dengan keluhan dispepsia pada mahasiswa fakultas kedokteran universitas nusa cendana tingkat akhir tahun 2015. Universitas Nusa Cendana

Rosanty, Rina. (2014). Pengaruh Musik Mozart dalam Mengurangi Stres pada Mahasiswa yang Sedang Skripsi. Journal of Educational, Health and Community Psychology

Sasmika, Azika. (2016). Hubungan pengetahuan spiritual terhadap pemenuhan kebutuhan spiritual: sholat dan thaharoh pasien stroke di Rumah Sakit Pusat Kesehatan Umum Muhammadiyah Gamping. Diakses pada tanggal 13 April 2018

Setyoadi. Kushariyadi, (2011). Terapi Modalitas Keperawatan Jiwa pada Klien Psikogeriatrik. Jakarta. Salemba Medika.

Sugiyono. (2016). Metode Penelitian Kuantitatif, Kualitatif, dan $R \& D$. Bandung. ALFABETA, CV

Sujarweni, Wiratna. (2014). Metodologi Penelitian Keperawatan. Yogyakarta

Sukadiyanto. (2010). Stress Dan Cara Menguranginya. Diakses Pada Tanggal 12 April 2018 
Swarjana, I Ketut. (2013). Metodologi Penelitian Kesehatan. Yogyakarta: ANDI.

Tutianty, Dkk. (2010). Penanganan Stress Pada Penyakit Jantung Coroner. Jakarta: Trans Info Media.

Tyani, Endar Sulis Dkk. (2015). Efektifitas Relaksasi Otot Progresif Terhadap Tekanan Darah Pada Penderita Hipertensi Esensial. Universitas Riau.

V, Kumutha Dkk. (2014). Effectiveness Of Progressive Muscle Relaxation Technique On Stress And Blood Pressure Among Elderly With Hypertension. IOSR Journal of Nursing and Health Science (IOSRJNHS).

Wulandari, Resti Putri. (2012). Hubungan Tingkat Stress Dengan Gangguan Tidur Pada Mahasiswa Skripsi Di Salah Satu Fakultas Rumpun Science-Technology UI. Universitas Indonesia. 